4. Arias-Goeta C, Mousson L, Rougeon F, Failloux AB. Dissemination and transmission of the E1-226V variant of chikungunya virus in Aedes albopictus are controlled at the midgut barrier level. PLoS One. 2013;8:e57548. http://dx.doi.org/10.1371/ journal.pone. 0057548

5. Moro ML, Gagliotti C, Silvi G, Angelini R, Sambri V, Rezza G, et al. Chikungunya virus in North-Eastern Italy: a seroprevalence survey. Am J Trop Med Hyg. 2010;82:508-11. http://dx.doi.org/10.4269/ajtmh.2010.09-0322

6. Sissoko D, Moendandze A, Malvy D, Giry C, Ezzedine K, Solet JL, et al. Seroprevalence and risk factors of chikungunya virus infection in Mayotte, Indian Ocean, 2005-2006: a populationbased survey. PLoS One. 2008;3:e3066. http://dx.doi.org/10.1371/ journal.pone. 0003066

7. Ayu SM, Lai LR, Chan YF, Hatim A, Hairi NN, Ayob A, et al. Seroprevalence survey of chikungunya virus in Bagan Panchor, Malaysia. Am J Trop Med Hyg. 2010;83:1245-8. http://dx.doi.org/10.4269/ajtmh.2010.10-0279

8. Yoon IK, Alera MT, Lago CB, Tac-An IA, Villa D, Fernandez S, et al. High rate of subclinical chikungunya virus infection and association of neutralizing antibody with protection in a prospective cohort in the Philippines. PLoS Negl Trop Dis. 2015;9:e0003764. http://dx.doi.org/10.1371/journal.pntd.0003764

9. Salje H, Cauchemez S, Alera MT, Rodriguez-Barraquer I, Thaisomboonsuk B, Srikiatkhachorn A, et al. Reconstruction of 60 years of chikungunya epidemiology in the Philippines demonstrates episodic and focal transmission. J Infect Dis. 2016;213:604-10. http://dx.doi.org/10.1093/infdis/jiv470

10. Gay N, Rousset D, Huc P, Matheus S, Ledrans M, Rosine J, et al. Seroprevalence of Asian lineage chikungunya virus infection on Saint Martin Island, 7 months after the 2013 emergence. Am J Trop Med Hyg. 2016;94:393-6. http://dx.doi.org/10.4269/ajtmh.15-0308

Address for correspondence: Anon Srikiatkhachorn, Institute for Immunology and Informatics, University of Rhode Island, 80 Washington St, Room 302F, Providence, Rhode Island 02903, USA; email: anons.gst@afrims.org

\section{Resurgence of Yellow Fever in Angola, 2015-2016}

\section{Antoinette A. Grobbelaar, Jacqueline Weyer, Naazneen Moolla, Petrus Jansen van Vuren, Francisco Moises, Janusz T. Paweska}

Author affiliation: National Institute for Communicable Diseases of the National Health Laboratory Service, Johannesburg, South Africa (A.A. Grobbelaar, J. Weyer, N. Moolla, P. Jansen van Vuren, J.T. Paweska); National Public Health Institute, Luanda, Angola (F. Moises)

\section{DOI: http://dx.doi.org/10.3201/eid2210.160818}

To the Editor: Yellow fever virus (YFV) is endemic in tropical and subtropical Africa and South America, and it is transmitted to humans and nonhuman primates through the bites of infected mosquitoes. The virus, a member of the family Flaviviridae, causes yellow fever, which in severe cases manifests as fulminant hemorrhagic fever. Outbreaks of yellow fever in humans occur mostly in the urban cycle of the virus, which involves its transmission through the bites of the day-feeding infected Aedes aegypti mosquitoes (1). As many as 130,000 cases with fever and jaundice or hemorrhage may occur annually with a concomitant 78,000 deaths (2). A low capacity for yellow fever diagnosis and lack of surveillance in disease-endemic countries likely contribute to case underreporting (1).

Although wide-scale yellow fever vaccination, which began in the 1940s and continued through 1960, resulted in a dramatic decrease in the number of outbreaks, waning population immunity and lapse of continued high coverage vaccination in yellow fever-endemic countries have led to the disease's resurgence in Africa (1-3). Between 1980 and 2012, the World Health Organization received reports of 150 outbreaks in 26 countries in Africa (2). In the past 5 years (2011-2016), outbreaks have been documented in Democratic Republic of Congo, Sudan, Cameroon, Chad, Senegal, Côte d'Ivoire, Uganda, and Sierra Leone (3). During 20052016, Sudan was the most affected country; 3 outbreaks were reported, resulting in 1,508 cases and 368 deaths $(3,4)$.

Yellow fever was first recognized in Angola in the 1930s, but not until 1971 (65 cases) and 1988 (37 cases) were sizeable outbreaks reported (5-7). As of July 1, 2016, a total of 3,552 suspected cases, including 875 laboratory-confirmed cases and 355 deaths, had been reported from all 18 provinces of Angola, with most cases occurring in Luanda Province (8). In this account, we provide laboratory confirmation that the first suspected viral hemorrhagic fever cases in Angola were YFV infections and report preliminary sequencing data.

On January 14, 2016, we received whole blood samples from 3 patients who resided in Luanda, Angola, and were suspected of having viral hemorrhagic fever. All were men, two 22 and one 30 years of age. Clinical manifestations in all patients were fever, headache, nausea, and vomiting. Myalgia, malaise, reduced consciousness, and jaundice each occurred in 2 patients; abdominal pain, back pain, ecchymosis, conjunctivitis, and bleeding gums each occurred in 1 patient. Two of the patients died 7 days after disease onset (online Technical Appendix Table, http://wwwnc.cdc.gov/EID/article/22/10/160818-Techapp1.pdf). Laboratory diagnosis consisted of testing for filoviruses, arenaviruses, and bunyaviruses, as well as for chikungunya and dengue viruses by using reverse transcription PCR (RT-PCR). All results of RT-PCRs were negative. A real time RT-PCR for YFV, targeting the $5^{\prime}$ noncoding region (9), produced positive results for samples from all 3 patients. The samples were then tested by using a pan-flavivirus RT-PCR targeting the flavivirus NS5 gene region using primers FU1 8993F and cFD2 9258R (10). Resulting amplicons of expected size (266 bp) obtained from 2 of the 3 samples were subjected to conventional Sanger sequencing. Phylogenetic 


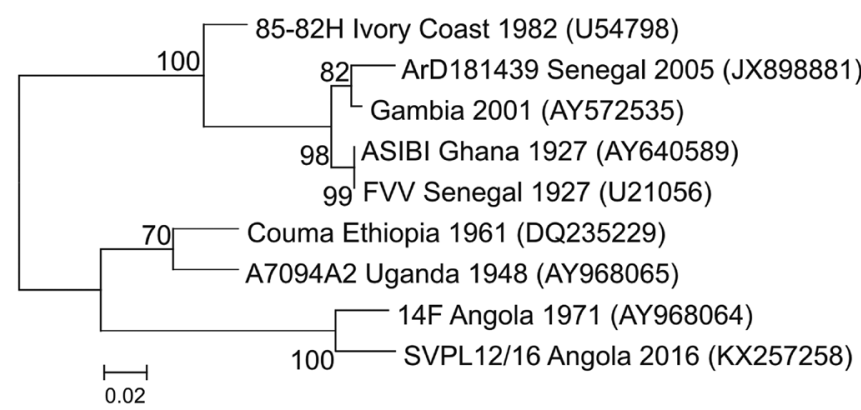

| West/Central Africa genotype

West Africa genotype

| East/Central Africa genotype

| East Africa genotype

Angola genotype
Figure. Maximum-likelihood phylogenetic reconstruction of $201 \mathrm{nt}$ of the NS5 gene of yellow fever virus in Angola and other recognized genotypes of the virus in Africa. Node values indicate bootstrap confidence values generated from 1,000 replicates. GenBank accession numbers are indicated in brackets. Scale bar indicates substitutions per site. analysis was performed by using a maximum-likehood method in MEGA version 6 (http://www.megasoftware.net) based on the general time reversible model under 1,000 bootstrap iterations, and sequence divergence was determined to calculate the p-distances between sequences. Phylogenetic inference of the sequence data demonstrated $95 \%$ nucleotide sequence similarity between the virus from this outbreak and the 14F YFV strain isolated in Angola in 1971 (Figure). PCR and sequencing results were reported to Angolan Public Health Institute on January 19, 2016.

The identification of the outbreak prompted cordon vaccination in Luanda in February 2016, followed by mass vaccination in other areas $(8)$. The initially localized outbreak in Angola developed into the biggest and most widespread yellow fever epidemic recorded in Africa for decades $(3,8)$. Sequencing and phylogenetic analysis indicate that the outbreak virus is highly similar to that identified during the epidemic in Angola in 1971. This finding reiterates the endemicity of yellow fever in Angola and emphasizes the need for consistent routine mass vaccination of the at-risk population to prevent future outbreaks.

\section{Acknowledgments}

We thank the Angolan Ministry of Health and the World Health Organization Country Office in Angola for technical support of this investigation.

The work was financially supported by the World Health Organization Collaborating Centre for Reference and Research on Viral Hemorrhagic Fevers and Arboviruses at the Centre for Emerging and Zoonotic Diseases of the National Institute for Communicable Diseases.

\section{References}

1. Gardner CL, Ryman KD. Yellow fever: a reemerging threat. Clin Lab Med. 2010;30:237-60. http://dx.doi.org/10.1016/j. cll.2010.01.001

2. Garske T, van Kerkhove MD, Yactayo S, Ronveaux O, Lewis RF, Staples JE, et al. Yellow fever in Africa: estimating the burden of disease and the impact of mass vaccination from outbreak and serological data. PLoS Med. 2014;11:e1001638. http://dx.doi.org/10.1371/journal.pmed.1001638

3. World Health Organization. Yellow fever. Emergency preparedness and response [cited $2016 \mathrm{Jul}$ 8]. http://www.who.int/csr/don/archive/ disease/yellow fever/en/
4. Markoff L. Yellow fever in Sudan. N Engl J Med. 2013;368:68991. http://dx.doi.org/10.1056/NEJMp1300772

5. Beeuwkes H, Mahaffy AF, Burke AW, Paul JH. Yellow fever protection test surveys in the French Cameroons, French Equatorial Africa, the Belgian Congo, and Angola. Trans R Soc Trop Med Hyg. 1934;28:233-58. http://dx.doi.org/10.1016/S0035-9203(34)90064-X

6. Pinto MR, Filipe AR. Arbovirus studies in Angola, Luanda. 1. Virological and serological studies during a yellow fever epidemic. Bull World Health Organ. 1973;49:31-5.

7. Vainio J, Cutts F. Yellow fever. WHO/EPI/GEN/9811. Geneva: World Health Organization; 1998. p. 1-87.

8. World Health Organization. Yellow fever outbreak in Angola. Situation report W26, 4 July 2016 [cited 2016 Jul 8]. http://www.afro.who.int/pt/yellow-fever/sitreps

9. Domingo C, Patel P, Yillah J, Weidmann M, Méndez JA, Nakouné E, et al. Advanced yellow fever virus genome detection in point -of-care facilities and reference laboratories. J Clin Microbiol. 2012;50:4054-60. http://dx.doi.org/10.1128/JCM.01799-12

10. Kuno G, Chang GJ, Tsuchiya KR, Karabatsos N, Cropp CB. Phylogeny of the genus flavivirus. J Virol. 1998;72:73-83.

Address for correspondence: Janusz T. Paweska, National Institute for Communicable Diseases of the National Health Laboratory Service, 1 Modderfontein Road, Sandringham 2131, Johannesburg, South Africa; email: januszp@nicd.ac.za

\section{Sexual Transmission of Zika Virus and Persistence in Semen, New Zealand, 2016}

\section{Jay Harrower, Tomasz Kiedrzynski, Simon Baker, Arlo Upton, Fahimeh Rahnama, Jill Sherwood, Q. Sue Huang, Angela Todd, David Pulford}

Author affiliations: Auckland Regional Public Health Service, Auckland, New Zealand (J. Harrower, S. Baker); Ministry of Health, Wellington, New Zealand (T. Kiedrzynski); Labtests and Northland Pathology Laboratory, Whangarei, New Zealand (A. Upton); Auckland District Health Board, Auckland (F. Rahnama); Institute of Environmental Science and Research Limited, Wallaceville, New Zealand (J. Sherwood, Q. Sue Huang, A. Todd); Ministry for Primary Industries, Wallaceville (D. Pulford)

DOI: http://dx.doi.org/10.3201/eid2210.160951 